\title{
ARTICLES
}

\section{WORKER "RIGHT TO KNOW" IN 30-YEAR RETROSPECT: DID WE GET IT RIGHT, WITH WHAT WE KNOW TODAY?}

James T. O’Reilly*

\section{TABle of Contents}

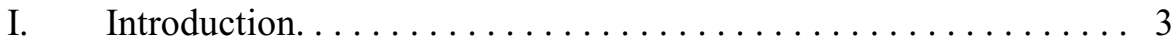

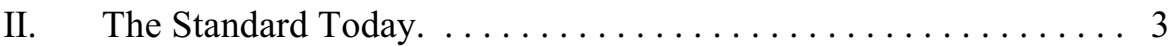

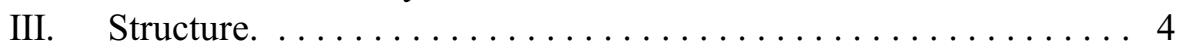

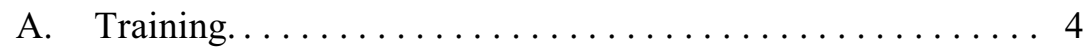

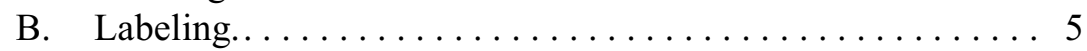

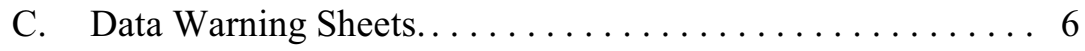

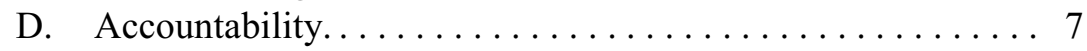

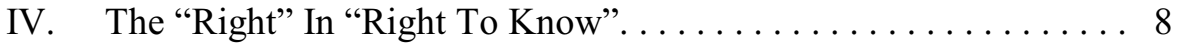

A. The Demand To "Know". .................. 9

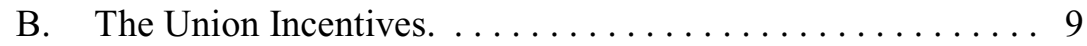

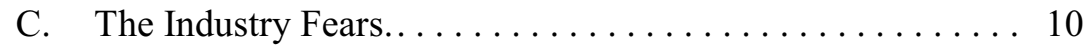

D. The Federal Process Begins. ............... 11

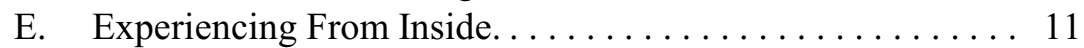

V. Foundations of the HazCom Standard................ 13

A. The Bingham Era....................... 14

B. The States Fill the Breach. . . . . . . . . . . . . . . . . 17

VI. The Political Change.................... 17

* College of Law, University of Cincinnati. 
VII. The Ability to Compel Speech. ... . . . . . . . . . . . . . . . . . 19

VIII. Spillover To Global \& Local "Right To Know"... . . . . . . . . . . 19

IX. Disappointment With Under-Utilization. . . . . . . . . . 20

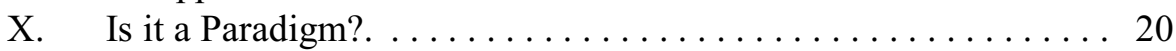

XI. Regulatory Capture, Or Not?.................. 22

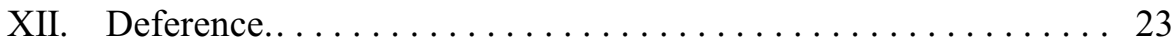

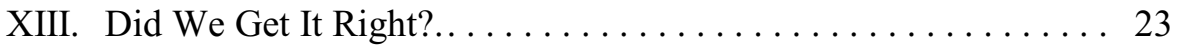

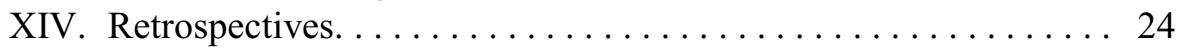

XV. Conclusion........................... 25 


\section{INTRODUCTION}

Three decades later, did we negotiators get it right? When in 2007 we passed the 30th anniversary of the first "right to know" workplace disclosure rules, ${ }^{1}$ should we who negotiated the rule reflect favorably on what was produced? And which of the competing sides, once labeled Doomsayers or Pollyannas, has been proven correct by the miraculous clarity of hindsight? We who were "present at the creation" of the Occupational Safety \& Health Administration ("OSHA") Hazard Communication Standard ${ }^{2}$ find the saga a mixture of success, frustration and unmet expectations. This essay offers one player's historical and policy retrospective, and I draw an ambiguous conclusion about an unsettled controversy.

The worker "right to know" movement was a brief but historic phenomenon in American labor law and regulation. It drew great attention and debate at the time, but there have not been many retrospective analyses of the net benefits from the movement's years of confrontation, agitation and litigation. Looking back in time from the internet era of today's "all news all the time," it may seem medieval to re-examine a time when workplace secrecy mattered greatly for the economic survival of American manufacturing industries.

This essay uses the term "right to know" advisedly. It was a highly charged political term with ramifications for the institutions and organizations that debated its potency. "Right to know" connotes both a source of rights and an act of knowing. The predicate for the first is a societal decision that a private person should have the right to another's information, for a collective purpose deemed important for society. The predicate for the second is that knowledge will have a beneficial effect on society, in this instance a beneficial aid to the self-protection of individuals exposed to a chemical substance.

\section{The Standard Today}

Virtually every workplace in the United States that handles any industrial goods complies with OSHA's Hazard Communication Standard" ("HazCom Standard," "HazCom" or the "Standard"), with more or less success in that

1. Occupational Safety \& Health Administration, Advance Notice of Proposed Rulemaking, 42 Fed. Reg. 5372 (Jan. 28, 1977).

2. 29 C.F.R. $\S 1910.1200(2006)$.

3. Id. 
compliance. HazCom is a mandatory regulation fixing a program of injury and illness avoidance through communications with workers. ${ }^{4}$ Its benefit is presently debatable, but will perhaps be manifest in several decades of retrospective epidemiology studies, showing before and after rates of chronic illness. In the beginning, in 1977-78, workplace exposure was assumed to cause twenty percent of cancer. ${ }^{5}$ Today, the data is inconclusive. Presumably a future statistical base of acute chemical injuries will be drawn, comparing 1970 s era mortality and morbidity rates with 1990s and 2010s era rates. Such a statistical base will be indicative of the effect of the standard on reduction of cancer, birth defects, and the acute harms of chemical spills, fires, splash and burn injuries.

The tangible signs of the HazCom Standard are visible in workplaces everyday. The Standard has engendered the ubiquitous presence of labels on chemical containers, the signs, posters and loose-leaf binders of Material Safety Data Sheets ("MSDS") that can be seen in hundreds of thousands of workplaces, and the video or in-person sessions of mandatory employee safety training that have been more or less well accepted as part of industrial worker training. Whether the self-protective behavior changes that were presumed to follow from expanded knowledge have in fact occurred remains debatable.

\section{Structure}

The four-part structure of the federal HazCom Standard requirements consists of training, labeling, data sheets, and accountability.

\section{A. Training}

HazCom requires training of workers regarding the hazardous chemicals to which they are exposed, ${ }^{6}$ and was intended to augment the training that they receive about other workplace hazards. The training exercise should get the workers' attention, provide the precautionary information, communicate how

4. U.S. Department of Labor Occupational Safety and Health Administration, Safety and Health Topics: Hazard Communication, http://www.osha.gov/SLTC/hazardcommunications/index.html (last visited May 27, 2007).

5. A 1978 federal report "estimates that 20 percent of cancers detected in the next few decades will be caused, at least in part, by workplace exposure." Council on Environmental Quality, Toxic Chemicals and Public Protection, Report to the President of the Toxic Substance Strategy Committee (May 1980).

6. 29 C.F.R. $§ 1910.1200(h)$. 
the risk can be avoided, and deal with questions. ${ }^{7}$ The mandate for training was a core provision of every draft of the HazCom rule at all stages, and OSHA's earliest instructions to its field inspectors told them to focus upon the records of training for workers and the content of the training. ${ }^{8}$

\section{B. Labeling}

The labeling of hazardous chemicals was the most costly aspect of the initial phase of the HazCom Standard, ${ }^{9}$ and it was the focal point of the original efforts to adopt a right to know regulation. Label warnings in the chemical industry are quite complex; ${ }^{10}$ they are best designed by applying a complex sub-science of communication theory and human factor studies. ${ }^{11}$ Industrial refinery pipes carry various chemicals through a maze, and placing and re-placing the current chemical contents labels on each pipe would have been quite costly. Industry advocates loudly protested such a command in early versions of the HazCom standard. Furthermore, labels that disclosed specific chemical identities would have disclosed details of secret formulas that provided chemical companies with a proprietary advantage over competitors. ${ }^{12}$

The details of the labeling rules in the HazCom Standard became the point of departure for the two sides, as unions demanded the label improvements but manufacturers vigorously challenged their attendant costs. The costs were high because the standard required an assessment of the probable exposures, an awareness of the chemical components of complex mixtures, and an appraisal of the risks that would have to be the subject of precautions on the label. HazCom was just one source of pressures concerning labels. Manufacturers were beginning to encounter the liability threats in personal injury cases involving worker-warning claims, ${ }^{13}$ and were

7. An OSHA model training program is found at http://www.osha.gov/dsg/hazcom/docs/ MTP101703.pdf (last visited May 27, 2007).

8. OSHA Compliance Directive, CPL 2-2.38A (May 16, 1986).

9. 29 C.F.R. $\S 1910.1200(f)$.

10. HANDBOOK OF WARnings (Michael Wogalter ed., 2006); HANDBooK of ChEMICAL IndUSTRY LABELING (Charles O'Connor \& Sidney Lirtzman eds., Noyes 1984).

11. See George Peters \& Barbara Peters, Warnings, Instructions and Technical Communications (1999); Kenneth Laughery et al., Human Factors Perspectives on Warnings (1994).

12. See James O'Reilly, Unions' Rights to Company Information 267 (Univ. Penna., Wharton School 1981).

13. See, e.g., Sprankle v. Bower Ammonia \& Chem. Co., 824 F.2d 409, 417 (5th Cir. 1987). 
struggling with communication methods, sizes, prominence, symbols, and various language issues. ${ }^{14}$

The worker today sees warning labels everywhere and accepts them as part of modern life. The worker in the period before HazCom did not see as many or as robust a set of warnings. Whether the current level of workplace warning signs actually encourages the positive behaviors of workers is a debate that requires more sociological and psychological research.

\section{Data Warning Sheets}

MSDSs existed before the 1980s. They were done by selected companies for selected workplaces, and sometimes were passed down by conscientious manufacturers to alert their customers of potential risks. By 2007, the MSDS has become a more complex document under HazCom. ${ }^{15}$ These sheets have blanketed workplaces and have consumed many forests' worth of paper over the decades, and the paper and ring-binder manufacturers have prospered. The MSDSs have exponentially increased in size and complexity from their rather humble beginnings. The sheets are now booklets of multiple pages providing information that the manufacturer or marketer hopes will fend off product liability lawsuits, whether or not workers in fact access the mandatory "readily accessible" sheets. ${ }^{16}$

The content of the MSDS includes the identity of each of the "hazardous" chemicals within the product, the risks of certain types of exposures, engineering and ventilation controls that the manufacturer recommends, any exposure limits recommended for a worker over an 8 hour shift, disposal and spill cleanup measures, the first aid measures if exposure occurs, long term toxicity effects, and other safety related information. ${ }^{17}$ Databases of MSDSs are widely available and are readily searchable by Google and other search engines. Health service providers have been enriched by the requirement that MSDSs must be accessible in virtually every manufacturing workplace.

14. Victor E. Schwartz \& Russel W. Driver, Warnings in the Workplace: The Need for a Synthesis of Law and Communication Theory, 52 U. CIN. L. Rev. 38 (1983).

15. 29 C.F.R. $\S 1910.1200$ (g) (2006).

16. 29 C.F.R. $\$ 1910.1200$ (g)(8) (2006).

17. Id. 


\section{Accountability}

For every "carrot" of encouragement, the federal enforcer has a "stick" with which to compel proper compliance with rules. Employer use of chemical safety information and training pre-existed the HazCom Standard, and this use was and remains laudable and positive for society. The accountability aspect of the HazCom Standard is the government power for enforcement of the Standard against firms that have not voluntarily chosen to inform their workers. ${ }^{18}$ The employer is accountable for failures and omissions of HazCom compliance. The inspection of the firm's training records, labels and MSDS collection is a routine part of virtually all federal and state OSHA site inspections. All of the penalty power of federal OSHA and the state OSHA agencies cannot make a program perfect. Nevertheless, they provide the "stick" that must accompany the "carrot" of outreach, "train the trainer" and other safety educational efforts of the government agencies. Enforcement is what makes this communication different from other employee training programs; each of the other aspects could have been done voluntarily had the company chosen to do so, but this is the "hammer" of compliance that imposes penalties for inadequacies in the HazCom program of individual employers.

Use of the enforcement mechanisms under state laws for the "state OSHA plan" skews the statistics on HazCom enforcement in a way that makes the statistics difficult to analyze separately by particular industry or year. HazCom violations were the largest number of federal inspector violation findings in the early years; they filled the dockets of the Occupational Safety $\&$ Health Review Commission's hearings in the early years of implementation. But because twenty-one states had opted to run their own OSHA program through their own state legal systems, ${ }^{19}$ it is impossible to statistically compile all of the HazCom related violations found in any particular industry or year nationwide. An OSHA presentation for the 2004 fiscal year showed that two aspects of the HazCom Standard were second and tenth most frequently cited among "serious" violations by OSHA inspectors. ${ }^{20}$ With all of the other

18. 29 U.S.C. $\S 658(2000)$

19. State Occupational Safety and Health Plans, http://www.osha.gov/dcsp/osp/index.html (last visited May 27, 2007).

20. OSHA Most Seriously Cited Violations, http://osha.ucsd.edu/FY2004\%20MFC-General\%20 Industry.ppt (last visited May 27, 2007) (stating absence of a written program for training, and deficient information and training, outscored many other sources of violations.) 
means by which worker risks can be reduced, it is significant that two of the top ten sources of enforcement cases come from this informational standard.

\section{The "Right" In "Right To Know"}

The right of access to private chemical data did not exist in the United States as a constitutional or statutory right for the nation's first two centuries. A profit oriented democracy respected individual property rights through the constitutional provisions for patents and through the Takings Clause in the Fifth Amendment. ${ }^{21}$ American law treated intangible property such as commercial knowledge as a source of individual property rights, manifest when sales of corporations included a valuation of the intellectual property, or when litigation affirmed that licensees could be forced to pay for the value of data that they had licensed from inventors of commercial trade secret information. The government policed the field of trade secrets ${ }^{22}$ as a protector of commerce, not a regulator of secrecy in chemical formulation data. ${ }^{23}$

Chemical data and product formulae were the classic "trade secrets" about which numerous court decisions were adopted. Indeed, the Supreme Court's Ruckelshaus v. Monsanto Co. decision ${ }^{24}$ recognized the reasonable investment-backed expectation of a private person that their chemical data would remain secret, even when shared with a federal agency for the limited purpose of safety evaluation in a government form titled "Confidential Statement of Formula." ${ }^{25}$ Thus, there are protectable license-related rights to ownership of the commercial information about chemical products; they had, for centuries, been the exclusive property of the chemical inventor and developer. For scholars of constitutional change, the alteration of chemical knowledge toward a public dissemination interest, rather than a private utility or licensing interest, is an intriguing re-orientation of property concepts.

21. U.S. Const. amend. V.

22. The term of art "trade secrets" is best defined in Restatement (SECOND) OF TORTS $\S 757 \mathrm{cmt}$.

23. The ability of the chemical identity owner to sue in state courts and obtain relief for improper taking of its secrets is illustrated in Kewanee Oil Co. v. Bicron Corp., 416 U.S. 484 (1974).

24. 467 U.S. 986 (1984).

25. This is a pesticide applicant's special disclosure to the Environmental Protection Agency of the precise recipe for making a proprietary pesticide product. 


\section{A. The Demand To "Know"}

The "right to know" social movement did not exist when a conversation among workers in a California chemical plant turned to the topic of children. Some of the workers had experienced stillborn children, others could not conceive, others had problems with newborns. The chemical plant made DBCP, a very effective pesticide for Central American banana crops. The workers wondered if the same toxic effect that was so desired with their product was proving to be effective on their own offspring. The workers of the California pesticide plant complained to their union, but the employer did not provide the information that they requested. ${ }^{26}$ Eventually, their national union headquarters solicited help of other local unions around the nation. All were asked to press for a right of access to chemical data that would enable workers, through collective bargaining, to have the information from which they could negotiate with factory managers for greater protective measures, clothing, ventilation, etc. ${ }^{27}$

The labor movement's agenda for state legislation soon included bills requiring chemical disclosure. Because the proposed federal rule was still very controversial, states were soon adopting their own disclosure laws, led by Oregon in 1977. Industry efforts to oppose these laws faltered in the face of a coalescence of union and environmental advocates. Label and data requirements varied among the states. Industry efforts to assert preemption of the states failed for lack of a final federal standard that could have preemptive force. ${ }^{28}$ So the federal process meandered toward adoption, while two dozen states filled the perceived gap with their own localized right to know rules.

\section{B. The Union Incentives}

The AFL-CIO member unions that followed the lead of the Oil, Chemical \& Atomic Workers were at a historic point of change when the "right to know" movement arose. Membership in private sector unions was descending to a low point in modern history. In the Midwestern and Eastern Rust Belt, large employers were closing and laying off unionized industrial workers as

26. This issue is addressed in detail in O'ReILLY, supra note 12, at 234.

27. Letter A-110 from A.F. Grospiron, Oil, Chemical \& Atomic Workers, to all local union presidents (Oct. 11, 1977) ("We need your cooperation in mounting an aggressive and methodical campaign to eliminate these hazards and make the workplace safe and healthful for all workers.")

28. West Virginia Mfrs. Assn. v. West Virginia, 542 F. Supp. 1247, 1253 (S.D. W. Va. 1982). 
they outsourced their manufacturing to other nations with lower costs. Individual workers were increasingly questioning the benefits received from the union dues withheld from their pay and wage stagnation appeared to make the idea that strikes could successfully increase the financial benefits from union membership less and less likely.

Looking back, an observer might note that the signs of malaise were setting in, as the dynamic union leadership of the 1950s and 1960s seemed to be ebbing away. The ability to re-energize and to carry on a crusade would be manifest with an issue that evoked health and personal rights, not just wages and pensions. So the "right to know" had tremendous public appeal as a cutting edge conflict, which legislators could address in order to score points with unions, and the issue would resonate with the press who have been champions of public access to governmental records.

Money isn't everything. Accordingly, if unions could not campaign on the promise of large pay increases, they could assert leadership in health protection efforts for workers exposed to chemicals. Fervent support by organized labor for improved protection of individual worker health and safety was seen in the early 1980 s as an antidote to the weakening health of industrial unions. It was prudent for the more energetic union leaders to push ahead with the demand for worker information, as a predicate to better worker protections, even though the push for increased wages had been blunted by global outsourcing.

\section{The Industry Fears}

Observers of the American chemical industry noted an atmosphere in the late 1970s of apprehension, if not fear, concerning chemical formulation disclosures. Erosion of market share in the worldwide market for specialty chemicals was the "doomsday scenario" of American chemical suppliers, during the 1977-85 period when HazCom was being negotiated. That scenario of severe competitive loss impacted on industry opposition to the mandate for public disclosure of chemical data. The specific chemical data would allow an international competitor to duplicate a specialized chemical product which otherwise would be sold as a U.S. export, which had been protected by "trade secret" status and by the difficulties of competitor "reverse engineering." The classic case was Borden Chemical's competition for the precise color additive needed to make the Coors beer can in its distinctive buff color. ${ }^{29}$ Industry 
feared the arrival of OSHA disclosure rules, because chemical makers sensed that American exports of chemicals, and American income from licensing the know-how of the products, would fall drastically if specialty chemical formulations had to be revealed.

\section{The Federal Process Begins}

The federal "right to know" efforts began in earnest in 1977 at the National Institute for Occupational Safety \& Health ("NIOSH"). NIOSH is a separate and supportive "sister agency" of OSHA and is part of the Centers for Disease Control in the Department of Health \& Human Services. The Institute gathers data, studies exposure and illness patterns, and recommends standards to be adopted by OSHA. The same 1970 statute that established OSHA the Occupational Safety \& Health Review Commission ("OSHRC") created NIOSH. ${ }^{30}$ The concept was that NIOSH would develop standards, OSHA would adopt and enforce the standards, and violators would be adjudicated by the separate hearings conducted by OSHRC. ${ }^{31}$

In 1977, managers in the incoming Carter Administration directed NIOSH to begin work on an OSHA chemical disclosure standard, and so an Advance Notice of Proposed Rulemaking was issued. NIOSH and OSHA soon encountered strident opposition from the chemical and oil industries. The controversy was fueled by a sharp conflict among competing interests: labor union demands, employer opposition, trade secrets of factory owners, Republican and Democratic antipathy for each other's policies, and the economic aspects of a rule imposing a requirement for the labeling of pipes and tanks inside complex factories. ${ }^{32}$ The atmosphere was heated and intense.

\section{E. Experiencing From Inside}

As a young participant on the industry side of this complex debate, beginning in 1978, I brought some experiences in each of the two conflicting worlds. I had been a union worker part time while in school and wrote my union's newsletter in a pre-law job. In addition, I served as law student assistant to former NLRB Chairman Frank McCulloch, through whom I met

\footnotetext{
competitor's plant, the competitive intelligence proved to be extremely helpful for Borden.

30. Williams-Steiger Occupational Safety and Health Act of 1970, Pub. L. No. 91-596, § 9, Dec. 29, 1970, 84 Stat. 1601.

31. The statutory scheme appears in 29 U.S.C. $\S 651$ et seq. (2000).

32. O'ReILly, supra note 12, at 226 et seq.
} 
some of the legendary giants of American industrial unionism in the early 1970s. Then as a new lawyer I had developed an expertise in the interface between regulation and trade secret law, having published articles and books on both. Thus the industrial associations brought me in to assist on HazCom, in the face of a perceived threat that regulatory controls would imperil innovative companies' ability to formulate and manufacture new chemicals that spark new lines of industrial success. The industry team's receptivity to compromise on trade secrecy and to the labeling suggestions I made was virtually zero.

The leaders of the industrial negotiation team and union negotiating effort were outwardly of similar appearance: older white males who had been hardboiled advocates for their respective views of the heavy industries that fed American productivity in what might be called the "pre-software age" of world competition. Watching their interaction, one saw scars from the classic battles of world views: industry distrusted unions, and unions expected the worst from management. I sensed the generational gap acutely from inside the defensive "circle of wagons" erected by chemical makers.

A benefit of the "right to know" effort was the paradox that it would use governmental power to empower a non-governmental force: the impetus for individual self-protection through greater self-awareness among workers about their exposures to risk. It would depend on forcing data owners to give information rather than restrict it to licensees. It would depend on workers to actually read the information and then to use the data to monitor their own protective behaviors. This project was to leverage OSHA punitive powers to press employers far beyond what the small number of OSHA inspectors could have accomplished.

The ironic aspects of this project were not lost on a generation of skeptics. The demographics of the younger working-age population were shifting toward "baby boomers" that were skeptical of both the militaryindustrial complex and the federal behemoth agencies that begat the Vietnam War. Other veterans and I entered industry and the professions with residual doubts about the honesty of big government. Meanwhile, the union drew energy from younger organizers trained in the anti-war movement, from which came their profound distrust of alliances among the bureaucracy and big industry. As negotiating adversaries, we were mutually cynical and skeptical about government. These paradoxes continued to simmer below the surface of the rulemaking for a decade and beyond. 


\section{Foundations of the HazCom Standard}

The story of this information-based Standard opens with the state of industrial chemical secrecy in the 1970s, against which the regulatory effort for disclosure was to be directed. The 1972-74 federal sampling of 4,636 workplaces by NIOSH found that seventy percent of the chemical mixture products were trade name products of unknown chemical components. ${ }^{33}$ And when NIOSH inquired, $32.5 \%$ of the chemicals were claimed to have trade secret ingredients. ${ }^{34}$ This survey suggested that a worker most likely would not know the chemicals to which he or she was exposed, and if inquiry had been made, at least one-third of the chemical identities would have been claimed proprietary secrets of the chemical supplier. In 1974, the U.S. Supreme Court had again affirmed that trade secrets in chemical mixture formulation were a valid form of property, protected by common law safeguards beyond the patent system. ${ }^{35}$ The federal Trade Secrets $\mathrm{Act}^{36}$ and provisions in the OSH $\mathrm{Act}^{37}$ and chemical regulatory laws ${ }^{38}$ protected trade secrets from disclosure.

In 1977, the federal agency experts on workplace safety, the NIOSH, published a book entitled, "The Right to Know." 39 The book stated that "[s]teps are being taken to promote voluntary disclosure." ${ }^{40}$ However, the economic incentive not to voluntarily disclose was very strong. Few unions had sufficient negotiating power to compel employers to disclose the chemical composition of workplace mixtures to either the employer or to the individual workers. ${ }^{41}$ Kodak, DuPont, Exxon and others reaped the rewards of trade secret licensing payments for their investments in chemical process research. Even if the customer's factory manager wanted to disclose the whole set of chemical ingredients to his or her employees, he or she could not compel most suppliers to part with the valuable formula data.

33. Natl. Inst. For Occ. Safety \& Health, The Right to Know (1977).

34. Id.

35. Kewanee Oil Co. v. Bicron Corp., 416 U.S. 470, 474, 493 (1974).

36. 18 U.S.C. $§ 1905$ (2000); see Chrysler Corp. v. Brown, 441 U.S. 281, 311-12 (1979).

37. 29 U.S.C. $\S 651$ et seq.

38. 15 U.S.C. $\$ 2613(2000)$.

39. NAtL. Inst. For OcC. SAFETy \& HeAlth, supra note 33.

40. Id.

41. The United Auto Workers was one of the few that had such power and had used it in negotiations with Ford Motor Company. 


\section{A. The Bingham Era}

The Carter Administration, entering office in 1977 on pledges to reform the post-Nixon atrophied regulatory system, found its workplace safety champion in OSHA Administrator Eula Bingham, a professor of industrial health who championed the information transfer concept. She endorsed the power sharing that would be manifest in part through greater flow of information to unions and workers. The Bingham leadership powered most of the early flow of action on HazCom, using consultants and union advocates to develop the outlines that could then be debated in the rulemaking process.

The initiation of the rulemaking in 1977 through an Advance Notice of Proposed Rulemaking ${ }^{42}$ was in part a result of the union efforts and in part a result of a petition filed late in 1976 by Public Citizen. ${ }^{43}$ The petition filed by Public Citizen sought mandatory disclosure of "the generic name of every chemical present in the workplace." 44

As industry realized, the administrative procedure steps for adopting an OSHA Standard ${ }^{45}$ slowed the process, facilitating industry's defense efforts. OSHA rulemaking consists of two tracks: a cumbersome one for occupational health standards and a faster track for more general rules. ${ }^{46}$ Creation of occupational safety standards must follow a lengthy prescribed process with extensive public input. Most other, routine OSHA rules that are not Standards need only allow paper comments and need not hold an oral proceeding. ${ }^{47}$ The OSH Act standards-setting provisions still today reflect the congressional compromises of 1970. And as the Supreme Court plurality saw in the 1980 benzene standards decision ${ }^{48}$ and the 1981 cotton dust decision, ${ }^{49}$ there were ambiguities in the statute that made the norms for standards more debatable. ${ }^{50}$

The first policy choice made by the Carter Administration was to bifurcate the issue; a Standard that required labels and training was separated

42. 42 Fed. Reg. 5372 (Jan. 28, 1977).

43. Petition to OSHA on Chemical Identification, Pub. Citizen, Sept. 27, 1976 (supplemented Nov. 17, 1977)

44. Id.

45. 29 U.S.C. $\S 655$ (2000).

46. The generally applicable 5 U.S.C. $\S 553$ (2000) is expressly inapplicable to OSHA Standards, 29 U.S.C. § 655(a) (2000).

47. 5 U.S.C. $\$ 553$.

48. Indus. Union Dep't v. Am. Petroleum Inst., 448 U.S. 607 (1980).

49. Am. Textile Mfrs. Inst. v. Donovan, 452 U.S. 490 (1981).

50. Indus. Union Dep't, AFL-CIO v. Am. Petroleum Inst., 448 U.S. 607 (1980); Am. Textile Mfrs. Inst., 452 U.S. at 490. 
from a smaller-scale rule that required disclosure of the ingredients of a workplace mixture to physicians or to a union. This second part became the Access to Employee Exposure \& Exposure Records rulemaking in 1978-80 with a final rule in $1980 . .^{51}$ The rule was challenged by industry but was upheld in the Louisiana Chemical case. ${ }^{52}$ It was a break in the dam that allowed select exposure data to pass for select recipients, but the rule was not a flood of information to the workers themselves,${ }^{53}$ as the HazCom had been intended to be.

After several years of hearings, meetings, speeches and policy debates, Dr. Eula Bingham of OSHA pressed for a Standard with a strong disclosure mandate. Inter-governmental conflict was a key tool for opponents who wanted to slow down OSHA. The rival regulators at the Environmental Protection Agency drafted their own rules on the same issue ${ }^{54}$ and competed with OSHA for primacy of the federal chemical-protective regulation world..$^{55}$ Industry opponents of HazCom wanted neither rule, but they benefited from the rivalry's distraction of both agencies. The Carter Administration had empowered the Office of Management and Budget (OMB) to clear agency regulations. This empowerment was a major disagreement among two potent regulators; the conflict was a principal reason why the HazCom was still pending at the time of the Reagan Administration re-direction of federal regulation.

The Carter Administration OSHA HazCom drafts were attacked on their cost and complexity, particularly as to pipe markings and signs. In the climate of close scrutiny to economic costs and benefits, more redrafts and more debates followed. Industrial advocates recognized that delay favored them. The complexity and uncertainty hampered the rule's proponents through multiple drafts. Industry fought hardest to protect the trade secrets contained in some chemical mixtures and specialty chemicals. Industry argued about the loss of licensing income that comes from exclusive possession of trade secret formula data. Losses, whether mandated by government or allowed

51. 45 Fed. Reg. 35212 (1980); 29 C.F.R. § 1910.1020 (2006).

52. Louisiana Chem. Ass'n v. Bingham, 550 F. Supp. 1136 (W.D. La. 1982).

53. The significance of this distinction is the empowerment of workers for self-help, a theme throughout the Carter Administration efforts, contrasted with the separate purpose of the Access standard to allow more informed diagnoses by physicians and health researchers.

54. EPA's authority came from the Toxic Substances Control Act, 15 U.S.C. $§ 2607$ (2000), and was arguably concurrent with OSHA as to workplace disclosures regarding chemical exposures.

55. The infighting among the federal agencies and states is explained in James O'Reilly, The Impact of Performance-Oriented Rules on Administrative Enforcement: The Case of OSHA Hazard Communication Rules, 2 A.B.A. LABor LaWyer 695 (1986). 
inadvertently by chemical firms, meant a reduction in income from licenses for the trade secret knowledge. In the Borden case, one innovative manufacturer related how it had won an important commercial advantage by accidentally learning the secret ingredient of its competitor, used in making the buff color on the front of the Coors beer can. ${ }^{56}$

The important first priority for cost/benefit critics of the HazCom rule was the elimination of a proposed HazCom requirement to label pipes with chemical information about the variable chemicals in a pipe at any given time. This requisite labeling constituted an absolutely huge cost for petroleum and chemical refiners. Lost productivity through a series of mandatory training sessions was another industry concern. Trade secrecy concerns pervaded all of the dialogues among OSHA, OMB, and industry. Negotiations evolved into posturing and political debates.

An election loomed ahead in 1980, adding pressure to the advocates and doubts among the Administration stewards of the regulatory portfolio. Industry lobbyists predicted that a more conservative electorate might disdain the larger cost of the new OSHA rule, and put their hopes on delay until the November 1980 election.

Ironically, the complementary ideals of transparency were the anchor that held back the HazCom advocates within OSHA. The policy movement favoring the worker "right to know," coupled with the policy movement for greater governmental awareness of costs and benefits of rules,${ }^{57}$ came together on a contemporaneous collision course in the Carter Administration's final year. There was hesitancy to move on the "right to know" issue until all of the details about costs were worked through, and this dragged out the process for many months during 1979-80. OSHA was simultaneously pushing a massive and complex cancer policy in a parallel rulemaking. In the heated debates about regulatory cost, OSHA was reviled by industry as the paragon of excessive regulatory controls, and this HazCom rulemaking played into the cost debates. With regard to the HazCom Standard itself, industry negotiators knew that their team would be the indirect beneficiaries of the other struggles OSHA was simultaneously encountering on other policies.

56. NLRB Case 32-CA-551, Brief of Borden Chemical, at 22 (June 22, 1979), discussed in O'ReILly, supra note 12, at $235 \mathrm{n} .9$.

57. Exec. Order No. 12044, 3 C.F.R. $§ 152$ (1978); see Am. Textile Mfrs. Inst. v. Donovan, 452 U.S. 490, 511-15 (1981). 


\section{B. The States Fill the Breach}

Delays in the federal process led to local frustration among union advocates, and to the subsequent adoption of state "right to know" laws. Approximately twenty-five states adopted laws or mandatory rules requiring various levels of hazard communication. ${ }^{58}$ The New Jersey worker and community "right to know" legislation was the most difficult for industry among the states that adopted some form of disclosure mandate. ${ }^{59}$ Several heavily unionized cities wrote their own ordinances on workplace chemical disclosure. $^{60}$

Industry saw the fragmentation and reluctantly began to favor a national norm through some modified OSHA rule. Major conflicts over the New Jersey law $^{61}$ and the Pennsylvania counterpart ${ }^{62}$ ended in industry association appeals to the Third Circuit for recognition of federal preemption powers. Preemption of states by a dominant federal rule would have to await the final adoption of a single federal HazCom Standard.

\section{The Political Change}

The labor movement and other "right to know" advocates pressed hard at the end of the Carter Administration for the adoption of a sweeping disclosure and training standard. However, this initiative became a futile anti-climax when President Carter lost his re-election effort. The Carter Administration's "right to know" rule and other "midnight rules" were published in the days immediately before President Ronald Reagan was inaugurated ${ }^{63}$ and were withdrawn twenty-seven days later by the new Administration. ${ }^{64}$ The Democratic Congress held hearings critical of the withdrawal, ${ }^{65}$ but the new

58. Ilisle L. Feitshans, Hazardous Substances in the Workplace, 3 Det. Coll. L. Rev. 697 (1985); O'ReILly, supra note 13, at 253 et seq.

59. James O’Reilly, Technology and Trade Secrecy: To Live and Die in N.J., 21 Seton Hall L. REV. 64 (1990).

60. James O'Reilly, Right to Know: Cincinnati's More Righteous, Less Knowing Experiment, 52 U. CIN. L. Rev. 337 (1983).

61. N.J. State Chamber of Commerce v. Hughey, 774 F.2d 587 (3d Cir. 1985).

62. Mfrs. Ass'n of Tri County v. Knepper, 801 F. 2d 130, 138 (3d Cir. 1986), cert. denied, 484 U.S. $815(1987)$

63. 46 Fed. Reg. 4412 (Jan. 16, 1981).

64. 46 Fed. Reg. 12020 (Feb. 12, 1981).

65. OSHA Oversight Hearings on Proposed Rules on Hazard Identification, Subcomm. On Health \& Safety of the House Comm. on Education \& Labor, 97th Cong. 1st Sess. (1981); Hearings on Hazard Communication, House Education \& Labor Comm., 97th Cong. 2d Sess. (1982). 
managers of the Labor Department were solidly favorable to industry's viewpoint on costly regulations.

The Reagan Administration proposed a weaker and narrower version of the HazCom rule in $1982 .{ }^{66}$ This weaker version deleted the costly requirement for labeling of pipes and made the rule a "performance" standard with more flexible means of accomplishing the communications with workers. ${ }^{67}$ Trade secret disclosure language was written with close attention to industry concerns. ${ }^{68}$ The new Administration conducted the hearings required by statute and heard extensive industry and union comments. ${ }^{69}$ Ultimately, the Hazard Communication Standard was made final in $1983 .{ }^{70}$ The Reagan HazCom was less detailed, more vague and friendlier to industry than the Carter version would have been. ${ }^{71}$ Industry had much closer input regarding the final standard; it became a performance-oriented rule, rather than a command and control rule. Therefore, the final standard allowed leeway that the Carter Administration versions had not envisioned, and unions and public interest groups sued for a broadening of the scope of the rule. The rule's coverage was later expanded, after appellate court directions for expansion were included in the Third Circuit decision upholding the final OSHA Standard. ${ }^{72}$

Once the federal standard was adopted, it triggered the preemptive powers of the federal OSH Act. In New Jersey State Chamber of Commerce v. Hughey, ${ }^{73}$ Manufacturers Association v. Knepper,${ }^{74}$ and Ohio Manufacturers Association v. Akron ${ }^{75}$ portions of the state and local disclosure laws were invalidated on grounds of federal preemption, but others remained in force.

\footnotetext{
66. 47 Fed. Reg. 12092 (1982).

67. Id.

68. 29 C.F.R. $\S 1910.1200(\mathrm{i})$ (2006).

69. The competing views at the hearings are addressed at 48 Fed. Reg. 53281 (1983).

70. 48 Fed. Reg. 53279 (1983).

71. See Susan Carle, A Hazardous Mix: Discretion to Disclose and Incentives to Suppress Under OSHA 's Hazard Communication Standard, 97 YALE L.J. 581 (1988), for an analysis of President Reagan's

72. United Steelworkers of Am. v. Auchter, 763 F.2d 728 (3d Cir. 1985).

73. 600 F. Supp. 606 (D.N.J. 1985), aff'd, 774 F.2d 587 (3d Cir. 1985)

74. 801 F. 2d 130, 138 (3d Cir. 1986), cert. denied, 484 U.S. 815 (1987).

75. 801 F.2d 824 (1986).
} HazCom policies. 


\section{The Ability to Compel Speech}

In constitutional terms, a governmental command to a private person to communicate with his or her employees is a form of compelled commercial speech under the First Amendment. The duty to pay one's workers to become trained about particular topics selected by government is controversial. When there are multiple state and local governmental commands to make different communications, as there were before the preemptive effect of the final HazCom Standard, the First Amendment issues and practical headaches of variability can become serious problems for manufacturers. These variant "right to know" requirements in some settings were "more righteous, less knowing" $"$ and the ultimate need for a balanced form of communication became evident.

The tens of millions of dollars spent on printing labels and sheets has been a remarkable investment in compelled communications. Much more spending would have been required for the pipe labeling in the original HazCom proposals. In a libertarian sense, compelling the posting of a communication is an intrusive governmental mandate that offends free speech norms. Nevertheless, the First Amendment issues did not win the arguments in the 1980s. The compelled private speech on so many other workplace issues has been upheld so frequently that the constitutional argument would probably still fail, even if raised again before the judiciary in today's more conservative federal appellate courts.

\section{Spillover To Global \& Local Right To Know}

HazCom set off two tangents of action-global attention to multiple national labeling schemes, and the community "right to know" movement. The former is so broad as to be beyond scope of this essay. ${ }^{77}$ The latter achieved a key objective in 1986 with adoption of a community disclosure requirement for hazardous and toxic chemicals in the Superfund amendments known as "SARA Title III." "78 More data about stored and processed chemicals is now available for community inspection than ever before, though

\footnotetext{
76. O'Reilly, supra note 60 , at 337.

77. Globally Harmonized System of Classification and Labeling Chemicals, http://www.osha.gov/dsg/hazcom/ghs.html (last visited May 27, 2007).

78. 42 U.S.C. $§ 11042(2000)$.
} 
apparently the legal right of access is little used by neighbors and communities. $^{79}$

\section{Disappointment With Under-Utilization}

Skepticism about the benefits of regulation is far more likely with an informational rule than with a bricks-and-mortar rule. If a pipe is required to be a certain thickness so it will not leak, one can measure effectiveness by the number of leaks. Information absorption by people cannot be measured the same way. Access requests or data inquiries would ordinarily be measurable, but the HazCom Standard does not require, and thus does not account for, the recording of users and numbers of uses. Relatively few users of the newly created rights came forward when the rules were first publicized ${ }^{80}$ What if the rule gave workers a right to access a record, and virtually no workers bothered to take that access? What if the employer created binders of MSDSs and no one read them?

Although many tens of millions of dollars have probably been spent on workplace implementation of $\mathrm{HazCom}$, there is too little information available regarding the actual utility and perceived utility to workers. More empirical data is needed on what has actually been the worker benefit of the right to know access. One cannot easily connect the dots: a worker accesses the material safety data sheet on a chemical; that worker understands and follows the precautionary instructions; that worker's exposure diminishes; that worker does not develop cancer or other chronic effects from exposure. We lack reliable data at each of these stages in the chain of benefits, especially lacking epidemiological proof of the absence of cancers that is connected to improved safety consciousness. It is not enough to say that it is intuitive that labels or training will lead to behavioral improvements.

\section{Is it A PARADIGM?}

The history of HazCom should not be anyone's role model for successful dispute settlement. Antagonists did not find middle ground. A presidential

79. Prior to the posting of internet data, the actual number of public requests for access to the files of accessible chemical data were remarkably small, though no national accounting of these individual access requests is known to exist. See Toxic Release Inventory (TRI) Program, www.epa.gov/tri/ (last visited May 27, 2007), for postings of many of the related chemical data items.

80. Caron Chess, Chemical Hazards at Work: Whose Business?, 9 Harv. Envtl. L. Rev. 331, 349 (1985) (stating that programs for education were developed in response to low public usage). 
election allowed opponents to cut back the strongest commands of the rule and the protagonists' response to federal delay, a proliferation of state and local laws, drove the industry to accept a limited federal "performance standard" in order to obtain nationwide certainty through federal preemption. The societal benefit of the "right to know" was to come through a reduction in illness and chemical related injury. The data does not exist to show a correlation in these past thirty years. Perhaps some future reader of this retrospective may have better fifty year figures to correct my skepticism long after I am departed.

The Reagan era deregulatory animus toward "command and control" rules with specific tasks has led to a "performance" standard in HazCom that avoided prescribing the precise methods of action, such as the words to be used on each product label. This performance oriented standard allowed companies to determine which items were "hazardous" instead of publishing a federal listing. ${ }^{81}$ This flexibility reduced costs to government, and put the onus on the private sector to select choices that would be compliant with the new rules. The private entities would do the hard work of technical analysis and labeling; the government would not need to write a comprehensive "bible" of all the chemicals to be labeled and of all the label elements for all of the chemicals. ${ }^{82}$ In lieu of a governmental decree as to which chemicals could be sold with which labels, the performance standard is a program focused upon responsible private actors, operating within a framework where their decisions could be reviewed by the agency and later, if necessary, by an adjudicator. ${ }^{83}$

The HazCom experience is not a good model for other informational communications, for several reasons. First, it showed that noble intentions of public interest-minded administrators to impose expensive mandates could be blunted by a very united and determined industry effort. In a democracy built on checks and balances, the checks sometimes predominate to the frustration of advocates. Neither side seemed willing to compromise during the Carter years. The result is a less efficacious protection than the program could have been.

Second, HazCom showed that inter-agency and federal-state conflicts will delay and diminish the efficacy of regulatory initiatives. The EPA conflict

81. 29 C.F.R. $§ 1910.1200$, app. B (2007) (describing criteria to be used in determining hazard status).

82. This reduced the size and complexity of the final Standard, but can arguably be said to have reduced the certainty of worker protections when the workplace is unsophisticated regarding the analyses required by app. B, id.

83. The administrative law judge of the Occupational Safety \& Health Review Commission will be adjudicating disputes concerning the Hazard Communication Standard; see 29 C.F.R. § 2200.67. 
with OSHA probably held back the Carter Administration from having a final rule in place before it left office. ${ }^{84}$ Had the OMB firmly ruled for OSHA to take the lead and push ahead, HazCom could have been fixed in place in 1979, not in 1983 and later.

Third, the HazCom "performance" approach for standards is arguably superior to a mandatory fixed set of commands, in terms of operational efficiency, but that approach shifted the obligations to private employers to "perform" appropriately. Some firms simply lack the ability to "perform" this way. The private sector bore the costs of consultants and instructors to work out the nuances. A conventional command and control rule gives a bright-line regulatory command, imposes fewer costs of translation, and takes fewer risks of misunderstandings. All of these benefits are linked with a significant cost because the rule must fix one nationwide norm. A performance rule is more flexible but therefore is more difficult to enforce.

\section{Xi. Regulatory Capture, Or Not?}

Conventional administrative law scholarship has viewed the effective "capture" of a regulatory agency by those it regulates as a disaster for the public interest. The constituency group that controls the agenda of the agency can dictate its actions, within limits of the available statutory powers. So what happens when electoral change brings a different agenda to dominate the "captive"?

HazCom involved the confrontation of political and economic forces on a complex issue, in a period of rapid political change. The Standard illustrates how capturing an agency and then losing hold of it to one's adversaries may make things worse for those who did the capture. The unions expected a certain outcome from their allies in the Carter Administration, and ultimately got much less. Electoral shifts led to Reagan-era deregulatory forces controlling the actual terms of the final rule, perhaps making the unions regret the hesitancy and uncertainties of the Carter era.

Viewed as an example of the seesaw of American political power, HazCom is an interesting sine curve on the graph of institutional powers. Labor union power in the Carter Administration propelled the rule to a point of adoption. After the conservative industry-backed forces made the death of that rule an integral part of their agenda at the dawn of the Reagan years, the

84. Hearings, Hazard Communication, House Education \& Labor Committee, 97th Cong. 2d Sess. (1982). 
rule was then rescinded ${ }^{85}$ Reining in runaway regulators at OSHA was a politically savvy approach for the conservatives in 1980-81. Were they runaway regulators, or was it simply a fiscally important ideological battle on which the election results of November 1980 had a deciding impact?

\section{Deference}

Deference by courts to the policy choices underlying the agency decision is an important aspect of modern rulemaking. The deference model of the Supreme Court's 1983 Chevron $^{86}$ decision is premised on a constitutional model of shared powers between the Executive, Legislative and Judicial branches. Chevron does not do well when the political forces change, leaving a policy to change with them. ${ }^{87}$ Thus the 1980 Carter draft rule, asserting a power drawn from an ambiguous statute, had the potential to earn deference. However, it did not become a final rule, and equally valid for the purposes of the Chevron deference norms was the Reagan final HazCom rule in 1983, which was upheld in the 1985 appeal. In both cases, the agency had expertise and had a meritorious claim for its policy selection.

\section{Did We Get It Right?}

Negotiating over decades on many other agency rules, I have thought about HazCom and its consequences. It is impossible to statistically conclude whether the money paid by industry for the workers' "right to know" has paid a "health dividend" commensurate with the large implementation and training expenditures. The metrics just do not exist. The American small business workplace is not dramatically different from those buildings or factories of the mid-1970s, though many of the large manufacturing workplaces have shrunk to fewer workers, more machinery and more computer-controlled systems. "Rust belt" unemployment, capital flight from hard-goods manufacturing, outsourcing, globalization, etc. have removed many workplaces entirely from presenting any chemical exposures at all. Industry had warned of job losses. Such losses occurred, but generally as a result of global forces larger than the HazCom disclosures.

85. 46 Fed. Reg. 12020 (Feb. 12, 1981).

86. Chevron USA Inc. v. Natural Res. Def. Council, 467 U.S. 387 (1984).

87. One illustration of the change in policies was that for automobile air bags; see Motor Vehicle Mfrs. Assn. v. State Farm Mut. Auto. Ins. Co., 463 U.S. 29 (1983). 
Success for a risk information requirement like HazCom would ideally be measured by a statistical reduction in cancer and chemical related harms. The rates of chronic disease and the types of cancer associated with industrial chemical exposures appear not to have lessened relative to the benchmark years. Nonetheless, this may have been a phenomenon related to other factors such as better detection capabilities, long years of smoking for an aging male work population, and other variables. Illness appearing after plant closure or layoffs might not be statistically associated with the former plant's exposure patterns.

The rates of penalty citations for HazCom violations appear to have diminished. Still, trends toward OSHA-industry cooperation, and the mixed nature of federal and state OSHA enforcement, make it difficult to garner a valid assessment of compliance.

\section{Retrospectives}

Looking back thirty years after the 1977 opening of the battle over the worker right to know, the debate seems an anachronism. Knowledge is a freeflowing commodity today with secrecy the exception. The internet, increased health consciousness, more worker education, larger training organizations among prudent manufacturers, and other aspects of the modern workplace are all favorable to worker self-protection. One can argue that chemical trade secrecy issues, one of the harshest fights in the HazCom Standard's evolution, are minor issues by today's measure.

The issue of labeling pipes with placards that would change with variable pipe contents, e.g. at an oil refinery, could have been compromised earlier by the rule's proponents. The projected implementation cost of pipe labeling handed a high-cost issue to the industry opponents of the entire rule, with which to invoke risk/cost analysis tools against the proponents.

An important mismatch of knowledge between would-be regulator and would-be client exists in technical standard-setting. The regulator lacks the ability to replicate the years of highly fact specific experience of the company upon whom the regulation is being imposed. Estimating the cost of labeling varied widely between government bureaucrats and chemical plant operators.

OSHA was not helped by the fact that some consultants were embarrassingly inept or overly conceptual. One personal favorite was the widely-circulated proposal by an OSHA consultancy to mail "sermon guides" to churches in the areas around chemical plants, giving the religious spin on the workers' right to know. This constitutionally dubious involvement with 
preaching Gospel verses to workers, with Labor Department funds, was retracted soon after it came to public attention.

In terms of a regulatory agency case study, the battle over the HazCom Standard should be examined by political science scholars as an example of what could have been. The fight would have been won by its labor advocates if the Carter Administration had acted more vigorously to direct EPA to back away from its competing efforts.

How could such an attractive concept as "right to know" lose? The industry team lacked Administration support during the Carter years, compared to the labor and environmental constituencies that held the reins of power. But industry had better facts about costs; a better public relations machine to emphasize costs; an implicit benefit from the bureaucratic infighting between OSHA and EPA; and the default position that no controversial standard could survive both the cumbersome nature of OSHA statutory provisions dealing with creation of standards and the OMB reviews of costs of new rules.

Have the impact predictions happened? The industry expression of fears of employment losses were probably well grounded in retrospect, but separating the costs of HazCom and the lost income from trade secret licensing are so difficult that only historians will be able to define where the HazCom Standard fits on a continuum of reasons for U.S. industrial manufacturing decline.

Did legal issues trump health issues? Perhaps. HazCom suffered from the heat put on OSHA over its Cancer Policy ${ }^{88}$ and its rollout of exposure limits, both of which encountered problems in the courts. The shifting sands of "substantial evidence" support and of deregulation were indirect influences on what the Carter Administration could have achieved.

\section{Conclusion}

To some, knowledge is power, and expanding knowledge about industrial chemicals can be presumed good for society as worker power expands the protection of worker health. To others, costs of regulation inhibit job retention, and the loss of an American manufacturing job will not easily be compensated by retraining the former skilled worker for a lower paid service role. 
The struggle over the "right to know" had drama, uncertain outcomes, and virtuous and not so virtuous actors and motives on each side. HazCom was intended to be a revolutionary improvement in health; it was a conflict that ended with a weakened compromise, as do so many others. For a young lawyer to have been present at the creation was a privilege; looking back leaves one with the assurance that democracy in administrative policymaking is messy, but necessary to achieving some movement in our complex society. 